\title{
X-Ray Repair Cross-Complementing Protein 6
}

National Cancer Institute

\section{Source}

National Cancer Institute. X-Ray Repair Cross-Complementing Protein 6. NCI Thesaurus.

Code C20023.

X-ray repair cross-complementing protein 6 (609 aa, $70 \mathrm{kDa})$ is encoded by the human XRCC6 gene. This protein plays a role in DNA non-homologous end joining, which is required for both double-strand break repair and $V(D) J$ recombination. 